\title{
Growth of Vibrio cholerae O1 Ogawa Eltor in freshwater
}

\section{Correspondence \\ Thomas Egli \\ egli@eawag.ch}

Received 13 December 2006

Revised 20 March 2007

Accepted 20 March 2007

\author{
Marius Vital, ${ }^{1,2}$ Hans Peter Füchslin, ${ }^{1}$ Frederik Hammes ${ }^{1}$ \\ and Thomas Egli ${ }^{1,2}$
}

${ }^{1}$ Swiss Federal Institute for Aquatic Science and Technology (Eawag), Überlandstrasse 133,
PO Box 611, CH-8600 Dübendorf, Switzerland
${ }^{2}$ Institute of Biogeochemistry and Pollutant Dynamics, ETH Zürich, 8092 Zürich, Switzerland

Growth of Vibrio cholerae O1 Ogawa Eltor was studied with a growth assay in which autoclaved and filtered $(0.22 \mu \mathrm{m})$ freshwater was inoculated at low cell density $\left(5 \times 10^{3}\right.$ cells $\left.\mathrm{ml}^{-1}\right)$ and proliferation was followed with flow cytometry. Against the common view, $V$. cholerae was able to grow extensively in different kinds of freshwater. The bacterium multiplied in river water, lake water and effluent of a wastewater treatment plant up to a cell density of $1.55 \times 10^{6} \mathrm{cells} \mathrm{ml}^{-1}$. In these samples, apparent assimilable organic carbon $\left(\mathrm{AOC}_{\mathrm{app}}\right)$ concentrations ranged from 52 up to $800 \mu \mathrm{g} \mathrm{I}^{-1}$ and the results demonstrate a positive trend between the $\mathrm{AOC}_{\mathrm{app}}$ concentration and final cell concentration, suggesting that AOC was a key parameter governing growth of $V$. cholerae. No growth was observed in waters (tap and bottled drinking water) containing less than approximately $60 \mu \mathrm{gOC}_{\text {app }} \mathrm{I}^{-1}$. When pure cultures of $V$. cholerae were grown on identical lake water at different temperatures $\left(20,25\right.$ and $\left.30{ }^{\circ} \mathrm{C}\right)$ the maximum specific growth rates $\left(\mu_{\max }\right)$ achieved were $0.22 \mathrm{~h}^{-1}, 0.32 \mathrm{~h}^{-1}$ and $0.45 \mathrm{~h}^{-1}$, respectively. In addition, growth was characterized in lake water samples amended with different concentrations of $\mathrm{NaCl}$. The highest $\mu_{\max }$ of $V$. cholerae was recorded at moderate salinity levels $\left(5 \mathrm{~g} \mathrm{NaCl} \mathrm{I}^{-1}\right.$, $\left.\mu_{\max }=0.84 \mathrm{~h}^{-1}\right)$, whereas at $30 \mathrm{~g} \mathrm{NaCl} \mathrm{I}^{-1}\left(\mu_{\max }=0.30 \mathrm{~h}^{-1}\right)$ or $0 \mathrm{~g} \mathrm{NaCl}^{-1}\left(\mu_{\max }=0.40 \mathrm{~h}^{-1}\right)$ specific growth rates were significantly reduced. In the water tested here, $\mu_{\max }$ of $V$. cholerae was always around $50 \%$ of that exhibited by a freshwater community of indigenous bacteria enriched from the water sampling site. Direct batch competition experiments between $V$. cholerae and the lake water bacterial community were performed at different temperatures in which $V$. cholerae was enumerated in the total community using fluorescent-surface antibodies. In all cases $V$. cholerae was able to grow and constituted around $10 \%$ of the final total cell concentration of the community. No significant effect of temperature was observed on the outcome of the competition. Mathematical modelling of the competition at the different temperatures based on the calculated $\mu_{\max }$ values confirmed these experimental observations. The results demonstrate that $V$. cholerae is not only able to survive, but also able to grow in freshwater samples. In these experiments the bacterium was able to use a large fraction (12-62\%) of the $A_{\text {app }}$ available to the bacterial AOC-test community, indicating that $V$. cholerae has the ability to gain access to the substrates present in freshwater even in competition with an autochthonous bacterial lake water consortium.

\section{INTRODUCTION}

Vibrio cholerae is able to adapt to both copiotrophic and oligotrophic environments: on the one hand, $V$. cholerae can promote disease by extensive growth in the human intestine; on the other hand it is also found amongst the

Abbreviations: $\mathrm{AOC}$, assimilable organic carbon; $\mathrm{AOC}_{\mathrm{app}}$, apparent assimilable organic carbon; DOC, dissolved organic carbon.

Two supplementary figures are available with the online version of this paper. autochthonous microbial flora of natural aquatic systems (West \& Lee, 1982). In natural waters the bacterium can be present in both a free-living state (Worden et al., 2006) or attached to copepods, zooplankters and algae (Lipp et al., 2002; Reidl \& Klose, 2002).

Previous laboratory studies have emphasized the influence of salinity on growth and, hence, the bacterium was considered to be naturally abundant in waters characterized by moderate or high salinity (Miller et al., 1982; Singleton et al., 1982a, b). Accordingly, V. cholerae O1 was 
frequently detected in estuary and coastal waters, and growth in sterile-filtered natural seawater under defined laboratory conditions has been reported (Binsztein et al., 2004; Louis et al., 2003; Mourino-Perez et al., 2003; Worden et al., 2006). In addition, laboratory studies using artificial seawater demonstrated growth of $V$. cholerae $\mathrm{O} 1$ down to a salinity of $5 \mathrm{~g} \mathrm{l}^{-1}$ (Singleton et al., 1982a, b). However, $V$. cholerae $\mathrm{O} 1$ has been detected frequently in freshwater as well (Yamai et al., 1996; Borroto, 1997), even in the absence of faecal index organisms (Bourke et al., 1986; Jesudason et al., 2000). Although freshwater systems are considered to be an environmental reservoir for $V$. cholerae (Shapiro et al., 1999), there is, as far as we are aware, no information available demonstrating the growth of this bacterium in freshwater.

In addition to salinity, temperature is reported to be a second important parameter controlling growth of $V$. cholerae in estuarine environments. Laboratory experiments showed a positive correlation between temperature and the metabolic activity of $V$. cholerae $\mathrm{O} 1$ in defined sea salt solution in a temperature range from 10 to $25{ }^{\circ} \mathrm{C}$ (Singleton et al., 1982a). Furthermore, a more frequent detection of $V$. cholerae $\mathrm{O} 1$ in estuary waters and a higher morbidity rate among people in Bangladesh was shown to be associated with increasing temperatures (Louis et al., 2003; Rodo et al., 2002).

As well as salinity and temperature, nutrients are considered to control growth of $V$. cholerae in aquatic systems (Colwell, 1996). In natural waters a key parameter governing microbial growth is assimilable organic carbon (AOC) (Van der Kooij, 1992). AOC is the small fraction $(0.1-10 \%)$ of the dissolved organic carbon, which is readily available for consumption by micro-organisms, resulting in cell proliferation (Hammes \& Egli, 2005). AOC is composed of low molecular mass compounds such as amino acids, sugars or organic acids (Egli, 1995; Münster, 1993). It is constantly produced through photosynthesis, viral lysis of bacterial cells, and biological and chemical hydrolysis of natural organic matter, and it is continuously consumed by the microbial flora. Residual AOC concentrations from $1 \mu \mathrm{g} \mathrm{l}^{-1}$ up to $2000 \mu \mathrm{g} \mathrm{l}^{-1}$ can typically be observed in natural waters (LeChevallier et al., 1991). AOC has been directly linked to bacterial regrowth in drinkingwater distribution systems (Van der Kooij, 1992). A relationship between the occurrence of coliform bacteria and AOC concentrations has been also shown in a full-scale study of drinking-water systems (LeChevallier et al., 1996). As most aquatic environments are usually oligotrophic and carbon/energy-limited (Morita, 1997), bacteria are continuously competing for AOC constituents. AOC is therefore an important factor in determining the microbial community composition in aquatic ecosystems.

Contaminated drinking water is one of the important transmission routes of the enteric pathogen $V$. cholerae and, therefore, data on the growth characteristics of this bacterium in freshwater are essential. The better the behaviour of $V$. cholerae in the natural environment is understood, the better hygienic measures can be taken in order to prevent the spread of this disease. For this reason, the growth of $V$. cholerae in freshwater was investigated and the influence of several selected environmental factors (salinity, AOC concentration and temperature) was studied. In addition, the growth of $V$. cholerae on nutrients in freshwater in competition with an autochthounous lake water bacterial community was investigated.

\section{METHODS}

Strains. Vibrio cholerae O1 (Biovar Eltor, serotype Ogawa, strain Nent 720-95) and Salmonella typhimurium ATCC 14028 were used in this study.

Preparation of carbon-free materials. Carbon-free glassware (bottles and vials) was prepared as described by Greenberg et al. (1993). In short: all glassware was first washed with common detergent, and thereafter rinsed three times with deionized water. These were then submerged overnight in $0.2 \mathrm{M} \mathrm{HCl}$ and subsequently rinsed with deionized water again and finally air-dried. The bottles and vials were heated in a muffle furnace at $550{ }^{\circ} \mathrm{C}$ for at least $6 \mathrm{~h}$. Teflon-coated screw caps for the glassware were similarly washed and treated with acid. Caps were thereafter soaked in a $10 \%$ sodium persulphate solution at $60{ }^{\circ} \mathrm{C}$ for at least $1 \mathrm{~h}$, rinsed three times with deionized water and finally air-dried.

Pre-cultivation of bacteria and growth in natural water. $V$. cholerae and $S$. typhimurium were cultivated in carbon-limited minimal medium (Ihssen \& Egli, 2004) containing $10 \mathrm{mg}$ glucose $1^{-1}$. Bacterial cells were sampled after 4 days of incubation during late stationary phase and directly inoculated to an initial concentration of $5 \times 10^{3}$ cells $\mathrm{ml}^{-1}$ into carbon-free glass vials $(40 \mathrm{ml})$ that contained autoclaved and $0.22 \mu \mathrm{m}$-filtered freshwater $(30 \mathrm{ml})$ originating from different sources. These vials were incubated at $30{ }^{\circ} \mathrm{C}$ and the total cell concentration was determined directly after inoculation (time 0 ) and at time $96 \mathrm{~h}$ when the stationary phase had been reached.

Preparation of natural water. Natural water was sampled with a $500 \mathrm{ml}$ Duran flask (Schott) and autoclaved within $30 \mathrm{~min}$. Subsequently, aliquots of $30 \mathrm{ml}$ were filtered using a $50 \mathrm{ml}$ LuerLok Syringe (BD) through a $0.22 \mu \mathrm{m}$ Millex syringe filter (Millipore) into $40 \mathrm{ml}$ carbon-free glass vials capped with a carbon-free PTFE/ silicone septa cap (Supelco). It should be pointed out that autoclaving $\left(20 \mathrm{~min}\right.$ at $121{ }^{\circ} \mathrm{C}$ ) was used as the method for sterilization, since it has been shown that filtration processes allow the passage of a fraction of bacteria present in freshwater (Hahn, 2004). After sterilization, samples were filtered in order to remove crystalline particles formed during autoclaving, which can interfere with the flow cytometric analysis. Different types of freshwater were used: tap water (community of Dübendorf, Switzerland), river water (Glatt River, Dübendorf, Switzerland), lake water (Lake Greifensee, Switzerland) and wastewater treatment plant effluent (WWTP; Glattbrugg, Switzerland). In addition, a dilution series of natural water $(0,10$, $25,50,75$ and $100 \%$ of Lake Greifensee water) was prepared using filtered $(0.22 \mu \mathrm{m}$ Millex filters) mineral water (Evian) as the diluent. These dilutions were subsequently autoclaved and again $0.22 \mu \mathrm{m}$ filtered.

AOC determination. AOC was determined with a batch growth assay as described previously (Hammes et al., 2006; Hammes \& Egli, 2005). In short: autoclaved and filtered water samples $(30 \mathrm{ml})$ were

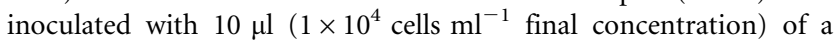


bacterial AOC-test community. These suspensions were then incubated at $30{ }^{\circ} \mathrm{C}$ for $96 \mathrm{~h}$ (until stationary phase was reached) and the resulting growth was measured with flow cytometry. The AOC inoculum originated from river water (Chriesbach River, Dübendorf, Switzerland) and was prepared as described by Hammes \& Egli (2005). The same bacterial community was used for all AOC determinations throughout the present study. As standard quality control prior to use, the performance of this inoculum was compared to bacterial AOC-test communities used in previous studies in our group (Hammes et al., 2006), using different types of natural surface waters as media. A difference of less than $\pm 10 \%$ in the mean AOC values was deemed acceptable for use. AOC $\left(\mu \mathrm{g}^{-1}\right)$ is estimated from cell concentrations (cells $1^{-1}$ ) using a theoretical conversion factor (Hammes et al., 2006; Van der Kooij, 2002); we will henceforth use the term 'apparent AOC' $\left(\mathrm{AOC}_{\mathrm{app}}\right)$ to express the data obtained with this method (equation 1). All assays were performed in triplicate. The detection limit of the method was $10-20 \mu \mathrm{g} \mathrm{AOC}_{\text {app }} 1^{-1}$ and the SEM was $\pm 10 \%$.

$\operatorname{AOC}_{\text {app }}\left[(\mu \mathrm{g} \mathrm{C}) 1^{-1}\right]=\frac{\left[(\text { net grown cells }) 1^{-1}\right]}{\left[1 \times 10^{7} \text { cells }\left(\mu \mathrm{g} \mathrm{C}^{-1}\right)\right]}$

Enumeration of total cell concentration. Absolute cell counting was performed with flow cytometry. Ten microlitres of SYBRgreen (Molecular Probes), $100 \times$ diluted in dimethylsulfoxide (Fluka Chemie AG), was added to $1 \mathrm{ml}$ of a bacterial suspension and incubated in the dark at room temperature for $15 \mathrm{~min}$ before analysis. All samples were measured on a PASIII flow cytometer (Partec) equipped with a $25 \mathrm{~mW}$ argon laser emitting at a fixed wavelength of $488 \mathrm{~nm}$ and volumetric counting hardware. Green fluorescence signals were collected at $520 \mathrm{~nm}$. The detection limit was 1000 cells $\mathrm{ml}^{-1}$ with an SEM of $\pm 5 \%$.

\section{Specific detection of $\boldsymbol{V}$. cholerae 01 by flow cytometry with} antibodies. A new method for specific detection of $V$. cholerae $\mathrm{O} 1$ with immunostaining was developed. Samples $(1 \mathrm{ml})$ collected from growth experiments were UVC-irradiated in a collimated beam apparatus (Metanor AG) with a fluence of $96 \mathrm{~J} \mathrm{~m}^{-2}$ to arrest growth. Then the sample was transferred into a flow cytometry vial (Sarstedt) and $10 \mu \mathrm{l}$ of the $V$. cholerae O1 DFA reagent (a fluorescent surface antibody) was added (New Horizons Diagnostics Corporation). The bacteria/antibody suspension was incubated for $30 \mathrm{~min}$ at $35{ }^{\circ} \mathrm{C}$ to let the antibody pre-adsorb to the bacterial surface. Subsequently, suspensions were further incubated for 12-17 h at room temperature in the dark to obtain a strong fluorescent signal. Finally, the concentration of immunostained $V$. cholerae $\mathrm{O} 1$ was determined by flow cytometry (as described above). To evaluate the staining efficiency, autoclaved and filtered freshwater samples were spiked with different concentrations of $V$. cholerae in the range of $10^{3}-$ $10^{5}$ cells $\mathrm{ml}^{-1}$ and the above procedure was applied immediately. Results were compared with cell counts obtained flow cytometrically with SYBRgreen staining. A linear correlation $\left(R^{2}=0.99\right)$ was observed over the whole range of cell concentrations tested. As a negative control, a sample $\left(10^{6}\right.$ cells $\left.\mathrm{ml}^{-1}\right)$ of the lake water bacterial community used for competition experiments was treated in exactly the same manner with the fluorescent antibody. No fluorescence was detected and thus it can be concluded that significant cross-reaction of the antibody with the lake water bacterial community did not occur. Note that staining efficiency of all immunostained samples was evaluated with epifluorescence microscopy as well.

Growth of $\boldsymbol{V}$. cholerae at different salt concentrations. For growth kinetic experiments at different salt concentrations, different volumes of an autoclaved $25 \% \mathrm{NaCl}$ stock solution were added to autoclaved and $0.22 \mu \mathrm{m}$-filtered freshwater samples of Lake Greifensee (Switzerland) to achieve the following final concentrations of $\mathrm{NaCl}: 0,1,5,10,20$ and $30 \mathrm{~g} \mathrm{l}^{-1}$. The $\mathrm{NaCl}$-amended water was subsequently inoculated with stationary-phase $V$. cholerae bacteria

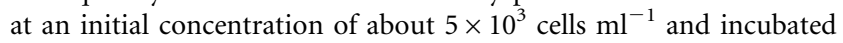
at $30{ }^{\circ} \mathrm{C}$. Cells of $V$. cholerae for inoculation were pre-grown in autoclaved and $0.22 \mu \mathrm{m}$-filtered freshwater of Lake Greifensee (Switzerland) amended with the same $\mathrm{NaCl}$ concentration as used for each specific experiment. The growth of the indigenous lake water bacterial community in autoclaved and $0.22 \mu \mathrm{m}$-filtered freshwater was recorded by removing $1 \mathrm{ml}$ samples at regular intervals and total cell concentration was measured as described above. All assays were performed in triplicate samples. The specific growth rate $(\mu)$ based on cell concentration increase was determined as follows:

$\mu=\left[\ln \left(N_{\mathrm{t}}\right)-\ln \left(N_{0}\right)\right] / \Delta t$

where $N_{\mathrm{t}}$ and $N_{0}$ are the cell concentrations measured at two subsequent time points and $\Delta t$ is the expired time interval between these points. We have measured an increase in cell concentration and not in biomass; thus, growth could also be described using the cellular division rate $(k)$, defined as the number of divisions per unit time . Since $k$ is not often used and values differ from that of $\mu(\mu=\ln 2 \times k)$, we decided to use the specific growth rate (equation 2) throughout the whole study.

Competition experiments. For these experiments a lake water bacterial community of natural origin and $V$. cholerae $\mathrm{O} 1$ grown on autoclaved and $0.22 \mu \mathrm{m}$-filtered lake water were used. The lake water bacterial community was sampled from the surface water $\left(4.1 \mathrm{mg} \mathrm{l}^{-1}\right.$ DOC; $22{ }^{\circ} \mathrm{C}, \mathrm{pH} 8.3$ ) of the eutrophic Lake Greifensee (Switzerland) and pre-cultivated as follows: $30 \mathrm{ml}$ autoclaved and $0.22 \mu \mathrm{m}$-filtered lake water was inoculated with $100 \mu \mathrm{l}$ untreated lake water from the same original sample. Suspensions were incubated at 20, 25 and $30{ }^{\circ} \mathrm{C}$, respectively, for 1 week and subsequently stored at $4{ }^{\circ} \mathrm{C}$ until further use. Culture density of the community was monitored with flow cytometry (see above).

Carbon-free $50 \mathrm{ml}$ glass vials containing $30 \mathrm{ml}$ autoclaved and $0.22 \mu \mathrm{m}$-filtered freshwater from Lake Greifensee were inoculated with either $V$. cholerae or the lake water bacterial community at an initial concentration of about $5 \times 10^{3}$ cells ml $^{-1}$, each. The cells used as an inoculum were pre-cultured on the same lake water at $30{ }^{\circ} \mathrm{C}$ and growth was monitored by recording the total cell concentration flow cytometrically at regular intervals. Cells were then sampled in the exponential-growth phase and directly inoculated into competition assays at $5 \times 10^{3}$ cells ml $\mathrm{ml}^{-1}$ of each partner (thus $10^{4}$ cells ml ${ }^{-1}$ initial total cell concentration). Assays were incubated at $30{ }^{\circ} \mathrm{C}$ and performed in triplicate. Samples of $2 \mathrm{ml}$ were collected at different time points throughout the competition experiment. Of these samples $1 \mathrm{ml}$ was used for determination of the total cell concentration and $1 \mathrm{ml}$ for immunological determination of the cell concentration of $V$. cholerae.

For competition experiments performed at different temperatures, the above pre-cultivation was performed at the relevant temperatures. The competition assays were started as described above. Samples were incubated at 20,25 and $30{ }^{\circ} \mathrm{C}$, respectively, for $48 \mathrm{~h}$, at which time the stationary phase had been reached. Subsequently, final concentrations of total cells and of $V$. cholerae, respectively, were determined as described above.

In addition, separate vials, containing the same autoclaved and $0.22 \mu \mathrm{m}$-filtered lake water as used for the competition experiments, were inoculated with exponential-phase cells from the pre-cultures of either $V$. cholerae or the lake water bacterial community at an initial concentration of $5 \times 10^{3}$ cells ml ${ }^{-1}$. The vials were then incubated at 20,25 and $30{ }^{\circ} \mathrm{C}$, respectively. Samples were taken at different time points from batch cultures and subsequently total cell concentrations were measured flow cytometrically. Specific growth rates $(\mu)$ were determined as described above (equation 2). 
Relative cell number yield. The relative cell number yield for $V$. cholerae, $Y_{V c / A O C}$, for growth on identical freshwater AOC is defined in equation 3. The total concentration of cells formed in freshwater samples was determined for $V$. cholerae and the bacterial AOC-test community in separate assays (as described above).

$Y_{V c / \text { AOCapp }}=\frac{\left[(\text { cells formed of } V \cdot \text { cholerae }) \mathrm{ml}^{-1}\right]}{\left[(\text { cells formed of a bacterial AOC-test community }) \mathrm{ml}^{-1}\right]}$

Simulation software. The simulation of growth and parameter estimation was carried out using AQUASIM software (Reichert, 1998). AQUASIM allows estimation of parameters by fitting predicted model data to experimental results. This feature was used to estimate kinetic parameters, which resulted in the best fit of simulations $\left(s_{\text {pred }}\right)$ and measurements $\left(s_{\mathrm{obs}}\right)$. The program estimated the best fit by minimizing $\chi^{2}$ values $\left(\chi^{2}=\sum\left[\left(s_{\text {obs }}-s_{\text {pred }}\right) / \sigma\right)^{2}\right]$. For the estimation the standard deviation $(\sigma)$ was set to $10 \%$ (if not determined experimentally).

\section{RESULTS}

\section{Growth of $V$. cholerae in different types of freshwater}

Stationary-phase cells of $V$. cholerae were inoculated into autoclaved and $0.22 \mu \mathrm{m}$-filtered mineral, tap, river, lake, and effluent water from a wastewater treatment plant in order to investigate its growth potential in different types of freshwater. Total growth was measured after $96 \mathrm{~h}$ by enumerating total cell concentration with flow cytometry. With the exception of mineral and tap water, $V$. cholerae showed extensive growth in all the freshwater samples tested (reaching final cell concentrations from $2.9 \times 10^{5} \mathrm{ml}^{-1}$ to $\left.1.55 \times 10^{6} \mathrm{ml}^{-1}\right)$. The growth of $S$. typhimurium was also tested in the same waters. In contrast to $V$. cholerae, S. typhimurium was unable to grow in any of the natural waters tested.

\section{Effect of salinity on the growth of $\boldsymbol{V}$. cholerae}

When $V$. cholerae cells were inoculated into autoclaved and $0.22 \mu \mathrm{m}$-filtered lake water amended with different concentrations of $\mathrm{NaCl}$, exponential growth of $V$. cholerae was observed after a short lag phase of about 2-4 h (Fig. 1a). The growth pattern of $V$. cholerae in freshwater followed the typical pattern observed for pure and mixed microbial cultures growing on complex media, consisting of an initial exponential growth phase at a constant $\mu$, followed by a continuously decreasing specific growth rate until stationary phase is reached. A considerable fraction of the cells was formed in the exponential growth phase (16-80\%), where cells exhibited a constant $\mu$. In the batches amended with $\mathrm{NaCl}, V$. cholerae occasionally showed a prolonged decelerating phase. In Fig. 2, the maximum specific growth rates $\left(\mu_{\max }\right)$ exhibited in the initial growth phase and the final cell concentration formed by $V$. cholerae are visualized as a function of $\mathrm{NaCl}$ concentration. The highest $\mu_{\max }$ was achieved at moderate salinity levels $\left(\mu_{\max }\right.$ at $5 \mathrm{~g} \mathrm{NaCl} \mathrm{l}^{-1}$ was as high as that of the lake water bacterial community in
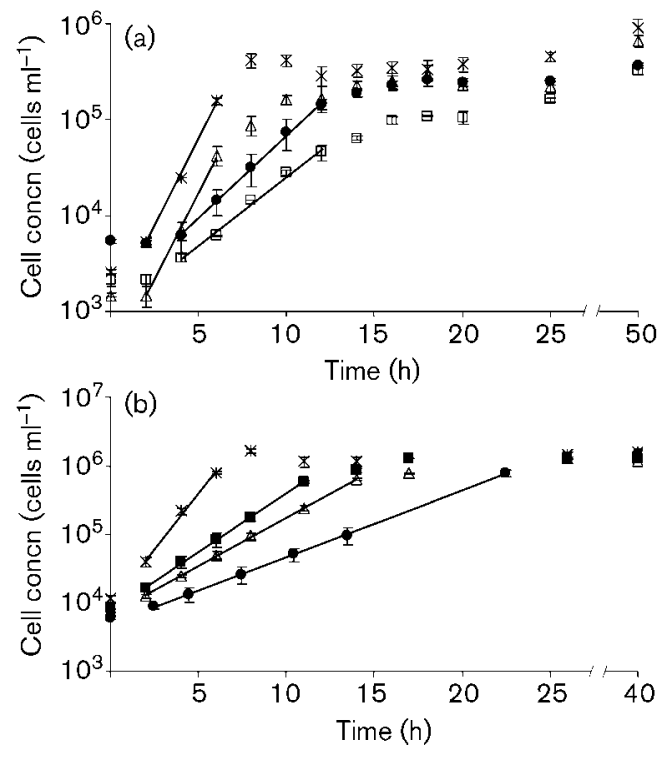

Fig. 1. Selected growth curves of $V$. cholerae cultivated in autoclaved and $0.22 \mu \mathrm{m}$-filtered freshwater. (a) Growth of $V$. cholerae in freshwater amended with different concentrations of $\mathrm{NaCl}\left(\mathrm{g} \mathrm{I}^{-1}\right): 0(\square) ; 5(\triangle) ; 30(\bullet) \mathrm{g} \mathrm{NaCl} \mathrm{I}^{-1}$. For comparison, growth for the lake water bacterial community at $0 \mathrm{~g} \mathrm{NaCl} \mathrm{I}^{-1}$ is shown $(\times)$. (b) Growth of $V$. cholerae in lake water at different temperatures $\left({ }^{\circ} \mathrm{C}\right): 20(\bullet), 25(\triangle), 30(\boldsymbol{\square})$. For comparison, the growth curve for the lake water bacterial community at $30{ }^{\circ} \mathrm{C}$ is shown as well $(x)$. The error bars indicate the standard deviation for triplicate samples. For the whole set of data see the supplementary material available with the online version of this paper.

freshwater), whereas at higher or lower salt concentrations, $\mu_{\max }$ was significantly reduced (Fig. 2). Furthermore, the maximum cell concentrations formed by $V$. cholerae followed a similar pattern as a function of the salt concentration as $\mu_{\max }$, with the highest cell concentration reached at moderate salinity (Fig. 2).

\section{Relationship between $\mathrm{AOC}_{\mathrm{app}}$ and growth of V. cholerae}

Growth can be affected by both the quality and quantity of nutrients. To assess this we compared $V$. cholerae growth in a dilution series of lake water (AOC quantity only varied) and in water from different sources (where both AOC quantity and quality vary). To assess the effect of AOC quantity, water from Lake Greifensee was diluted with a water sample that did not support growth of $V$. cholerae (Evian, $52 \mu \mathrm{g} \mathrm{AOC}_{\text {app }} \mathrm{l}^{-1}$ ). This resulted in a dilution series that ranged from approx. 52 to $300 \mu \mathrm{g} \mathrm{AOC}_{\mathrm{app}} \mathrm{l}^{-1}$. A linear correlation $\left(r^{2}=0.98\right)$ between $\mathrm{AOC}_{\mathrm{app}}$ concentration originating from Lake Greifensee and final cell concentration of $V$. cholerae was observed (Fig. 3a).

In a subsequent experiment, water from different sources was sampled, the $\mathrm{AOC}_{\mathrm{app}}$ concentration was determined 


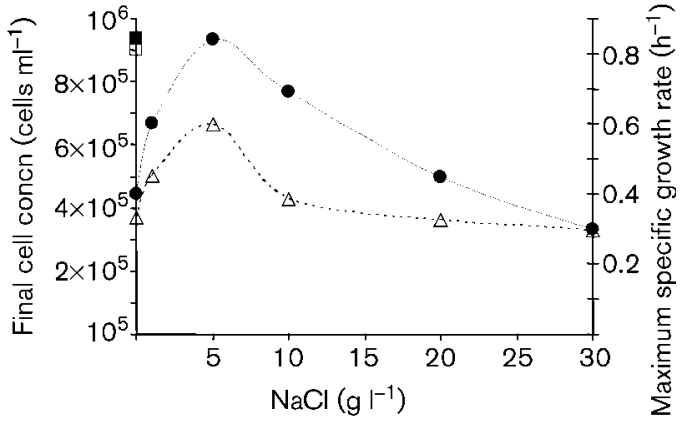

Fig. 2. Growth of $V$. cholerae in autoclaved and $0.22 \mu \mathrm{m}$-filtered river water amended with different concentrations of $\mathrm{NaCl}\left(\mathrm{g} \mathrm{I}^{-1}\right)$. Maximum specific growth rates $\left(\mathrm{h}^{-1}\right)$ of $V$. cholerae $(\mathbf{0})$ and the maximum cell concentration of $V$. cholerae $(\triangle)$ reached as a function of the $\mathrm{NaCl}$ concentration are shown. For comparison $\mu_{\max }(\boldsymbol{\square})$ and the final cell concentration $(\square)$ for the lake water bacterial community at $0 \mathrm{~g} \mathrm{NaCl} \mathrm{I}^{-1}$ in the same water are shown as well. The maximum specific growth rate was determined from the linear part of the exponential growth curves shown in Fig. 1 (and the supplementary data).

and the growth of $V$. cholerae was examined (Fig. 3b). Here also, a positive trend between $\mathrm{AOC}_{\mathrm{app}}$ concentration and the total growth of $V$. cholerae was observed, although the correlation was much lower $\left(r^{2}=0.36\right)$. Nevertheless, with increasing $\mathrm{AOC}_{\text {app }}$ concentrations, higher final cell concentrations of $V$. cholerae were formed. The cell number yields of $V$. cholerae in relation to that of the bacterial AOC-test community (equation 2) were rather variable, ranging from $Y_{V c / A O C a p p} 0.12$ to 0.62 with a mean of 0.28 . Waters containing very low amounts of $\mathrm{AOC}_{\mathrm{app}}$ (tap water with $44 \mu \mathrm{g} \mathrm{l}^{-1}$, and bottled drinking water with $52 \mu \mathrm{g} \mathrm{l}^{-1}$ ) did not support growth of $V$. cholerae.

\section{Competition of $\boldsymbol{V}$. cholerae with a lake water bacterial community}

The ability of $V$. cholerae to compete in batch culture with a lake water bacterial community was tested in autoclaved and filtered lake water at $30{ }^{\circ} \mathrm{C}$ (Fig. 4). The results show that $V$. cholerae was able to use a part of the available substrates for growth and could even grow when competing with the indigenous lake water bacterial community (starting from a similar initial concentration of $4.13 \times 10^{3}$ $V$. cholerae cells $\mathrm{ml}^{-1}$ and $2.84 \times 10^{3}$ cells $\mathrm{ml}^{-1}$ of a lake water bacterial community, respectively). A simultaneous exponential increase in the concentration of cells was observed for both $V$. cholerae and total bacterial cells. In these experiments, a lag phase was successfully avoided by pre-culturing the two inocula in the same freshwater sample as used also in the competition experiment and by inoculating cells from the exponential-growth phase. The mean final cell concentration of $V$. cholerae after $22 \mathrm{~h}$ (stationary phase) was $9.73 \times 10^{4} \pm 1.31 \times 10^{4}$ cells $\mathrm{ml}^{-1}$,

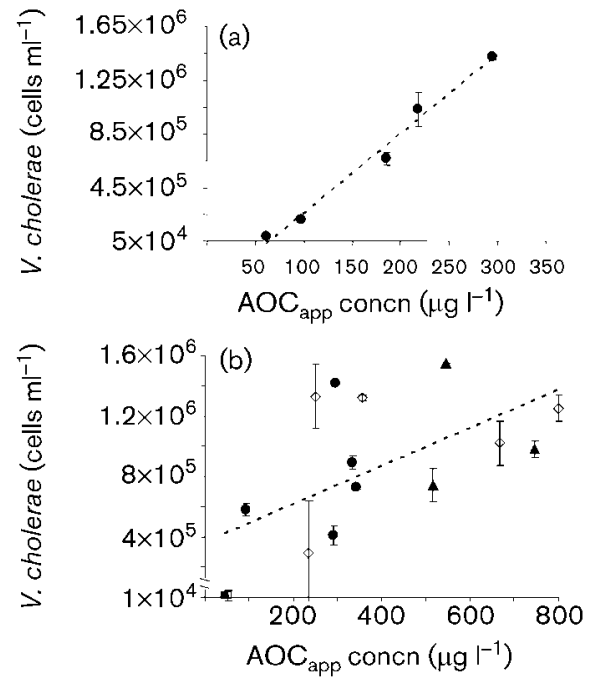

Fig. 3. Correlation between $\mathrm{AOC}_{\mathrm{app}}$ concentration and the final cell concentration of $V$. cholerae reached in the stationary phase of batch cultures. The final cell yield of $V$. cholerae is dependent on both the AOC concentration and the composition or quality of the AOC present in a water body. (a) Correlation between growth of $V$. cholerae ( $)$ and different concentrations of $A O C_{a p p}$ of the same quality. Autoclaved, sterile-filtered lake water was used. The concentration of $\mathrm{AOC}_{\mathrm{app}}$ resulting from the diluent (bottled mineral water) was subtracted in the individual dilutions, indicated on the $x$-axis. It is therefore not considered in the linear regression analysis $\left(r^{2}=0.98\right)$. (b) Correlation between $\mathrm{AOC}_{\text {app }}$ concentration and growth of $V$. cholerae on autoclaved sterile-filtered freshwater from different sources (i.e. with AOC of different quality). The different water samples [tap water Eawag, Dübendorf $(\boldsymbol{\square})$, bottled drinking water $(\square)$, river water $(\bullet)$, Lake Greifensee water $(\diamond)$ and effluent of a sewage treatment plant $(\boldsymbol{\Lambda})$ ] were collected on different days. Error bars indicate the standard deviation for triplicate samples. $\mathrm{AOC}_{\mathrm{app}}$ concentration was determined according to Hammes \& Egli (2005) with a standard bacterial AOC-test community as described in Methods.

which represents $9.7 \%$ of the total bacterial concentration $\left(1 \times 10^{6} \pm 3.50 \times 10^{4}\right.$ cells $\left.\mathrm{ml}^{-1}\right)$.

To test whether or not it is possible to predict the outcome of the competition with a simple growth model, the individual maximum specific growth rates of $V$. cholerae and of the lake water bacterial community were determined in a separate experiment during growth in sterilized, identical freshwater samples and were found to be $0.34 \mathrm{~h}^{-1}$ and $0.50 \mathrm{~h}^{-1}$ for $V$. cholerae and the lake water bacterial community, respectively. It was possible to simulate the population dynamics by applying the simplest growth model $\left(\mu=\mu_{\max }\right)$ using the previously determined $\mu_{\max }$ of the pure cultures over the whole batch experiment until all the available nutrients were used up (Fig. 4). This is a strong hint that this is a case of 'pure and simple' competition for nutrients and that no other interaction was taking place between $V$. cholerae and the lake water bacterial community. 


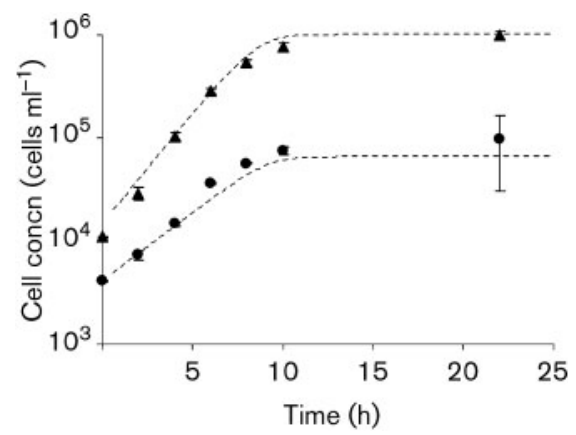

Fig. 4. Growth of $V$. cholerae in autoclaved and $0.22 \mu \mathrm{m}$-filtered lake water in competition with a lake water bacterial community at $30{ }^{\circ} \mathrm{C}$ in batch culture. Experimental data of $V$. cholerae $(\mathbf{O})$, total counts $(\boldsymbol{\Delta})$ and mathematical simulations (dashed lines) using $\mu_{\max V c}=0.34 \mathrm{~h}^{-1}$ and $\mu_{\max L W B C}=0.50 \mathrm{~h}^{-1}$. Error bars indicate the standard deviations for triplicate samples.

\section{Effect of temperature on growth of $V$. cholerae and competition with the lake water bacterial community}

To investigate the effect of temperature on growth and competition, similar experiments were performed at 20, 25 and $30{ }^{\circ} \mathrm{C}$. First, batches of autoclaved and $0.22 \mu \mathrm{m}$ filtered lake water were inoculated separately with either a lake water bacterial community or $V$. cholerae, respectively, and $\mu_{\max }$ was determined. Selected corresponding growth curves are presented in Fig. 1(b) and the respective values for $\mu_{\max }$ are listed in Table 1 . In all these experiments an extended phase of exponential growth at $\mu_{\max }$ was observed for both $V$. cholerae and the lake water bacterial community, with only $50 \%$ of the total cells formed in the second decelerating phase of growth.
The fact that the ratio of the maximum specific growth rates of $V$. cholerae and the lake water bacterial community (LWBC), i.e. $\mu_{\max V d} / \mu_{\operatorname{maxLWBC}}$, was virtually the same at all temperatures suggests little advantage or disadvantage of $V$. cholerae to compete for nutrients with the lake water bacterial community within the temperature range tested.

In addition, competition experiments were performed in the same sterile freshwater samples at $20{ }^{\circ} \mathrm{C}, 25{ }^{\circ} \mathrm{C}$ and $30{ }^{\circ} \mathrm{C}$. As before, equal cell concentrations were inoculated and the final concentrations of $V$. cholerae and total bacterial cells were enumerated in the stationary phase after $48 \mathrm{~h}$ when all substrates had been consumed (Table 1). In all experiments $V$. cholerae proliferated from initially $5 \times 10^{3}$ cells $\mathrm{ml}^{-1}$ during competition with the lake water bacterial community to $1.3 \times 10^{5}$ cells $\mathrm{ml}^{-1}\left(20{ }^{\circ} \mathrm{C}\right)$, $1.76 \times 10^{5}$ cells ml $^{-1}\left(25^{\circ} \mathrm{C}\right)$ and $1.97 \times 10^{5}$ cells ml $^{-1}$, respectively. The final fraction of the bacteria was around $10 \%$ of the total bacterial cells at all temperatures tested. All this suggests that within the temperature range tested, the fitness of $V$. cholerae was not affected compared to that of the lake water bacterial community. In Table 1, the results of the simulation using the same simple growth model used in Fig. 4 by applying the previously determined $\mu_{\max }$ of the pure cultures are also listed. They are in good agreement with the experimentally determined values.

\section{DISCUSSION}

Although determination of bacterial growth rates in nature - particularly in the marine environment - is an intensively investigated and much discussed research area (Ducklow \& Carlson, 1992; Hagström et al., 1979, 1984; Moriarty, 1986; Robarts \& Zohary, 1993; Simon et al., 2002), studies concerning the kinetics of growth of waterborne bacterial

Table 1. Competition in batch culture of $V$. cholerae $\left(V_{c}\right)$ and a lake water bacterial community (LWBC) for nutrients present in lake water at different temperatures

Autoclaved and $0.22 \mu \mathrm{m}$-filtered water from Lake Greifensee was inoculated with similar concentrations of $V$. cholerae and a lake water bacterial community $\left(5 \times 10^{3}\right.$ cells $\mathrm{ml}^{-1}$, each). The concentrations of total cells and of $V$. cholerae, respectively, were enumerated $48 \mathrm{~h}$ after inoculation when stationary phase had been reached. The predicted fraction of $V$. cholerae at the end of growth is based on a simulation with previously determined $\mu_{\max V c}$ and $\mu_{\operatorname{maxLWBC}}$ on the same water. Maximum specific growth rates were determined in separate assays and corresponding growth curves for V. cholerae are shown in Fig. 1(b) (and in the supplementary figures available with the online version of this paper).

\begin{tabular}{|c|c|c|c|}
\hline & $20{ }^{\circ} \mathrm{C}$ & $25{ }^{\circ} \mathrm{C}$ & $30{ }^{\circ} \mathrm{C}$ \\
\hline Bacterial concentration (total cells $\mathrm{ml}^{-1}$ ) & $1.74 \pm 0.22 \times 10^{6}$ & $1.72 \pm 0.20 \times 10^{6}$ & $1.89 \pm 0.13 \times 10^{6}$ \\
\hline V. cholerae (cells $\mathrm{ml}^{-1}$ ) & $1.30 \pm 0.13 \times 10^{5}$ & $1.76 \pm 0.30 \times 10^{5}$ & $1.97 \pm 0.10 \times 10^{5}$ \\
\hline$V$. cholerae (\% of total cell concn) & $7.5 \pm 0.6$ & $10.2 \pm 1.3$ & $10.4 \pm 1.0$ \\
\hline $\begin{array}{l}\text { Predicted fraction of } V \text {. cholerae } \\
\text { (\% of total cell concn) }\end{array}$ & 7.0 & 7.1 & 7.3 \\
\hline$\mu_{\max V c}\left(\mathrm{~h}^{-1}\right)$ & $0.218 \pm 0.008$ & $0.321 \pm 0.004$ & $0.449 \pm 0.001$ \\
\hline$\mu_{\operatorname{maxLWBC}}\left(\mathrm{h}^{-1}\right)$ & $0.418 \pm 0.018$ & $0.641 \pm 0.006$ & $0.884 \pm 0.009$ \\
\hline Ratio $\mu_{\max V d} / \mu_{\operatorname{maxLWBC}}$ & 0.52 & 0.50 & 0.47 \\
\hline
\end{tabular}


pathogens and their competition with indigenous microbial flora for natural organic carbon are rare. This is mainly due to the lack of methods for easily monitoring the growth of microbial cells of a mixed community (most of them are 'unculturable') at the low concentrations of substrates and biomass typical for environmental conditions. Here we have used flow cytometry in combination with fluorescent nucleic acid staining of cells to monitor the growth of mixed microbial communities. For the specific detection of $V$. cholerae we have developed a flow cytometric method based on cell-surface fluorescent antibodies to enumerate this pathogen in the presence of indigenous freshwater bacterial flora. This combination of techniques allowed us to study the kinetics of growth of the enteric pathogen and its competition for nutrients with a lake water bacterial community in a laboratory system.

Our studies demonstrate for the first time that $V$. cholerae is not only able to survive (Nogueira et al., 2002), but even able to grow in freshwater. In general, $V$. cholerae grew in autoclaved and $0.22 \mu \mathrm{m}$-filtered freshwater in batch culture, exhibiting first a short lag, then exponential growth with a constant $\mu_{\max }$ over an extended period of time, which was followed by a decelerating phase of growth and a stationary phase (as commonly seen with, for example, pure cultures of Escherichia coli growing on complex medium at much higher substrate and cell concentrations). The specific growth rates achieved by $V$. cholerae during proliferation in sterilized freshwater were roughly $50 \%$ of those observed under optimum salt concentrations (identical freshwater amended with $5 \mathrm{~g}$ $\mathrm{NaCl} l^{-1}$ ). Under such optimum conditions, $V$. cholerae reached a surprisingly high $\mu_{\max }$, which was similar to that exhibited by the lake water bacterial community on the same freshwater $\left(\mu_{\max }=0.84 \mathrm{~h}^{-1}\right)$.

Earlier reports, based on the distribution of $V$. cholerae in estuarine water, had already indicated the preference of this pathogen for moderate salinity with respect to optimum conditions for growth (Huq et al., 2005; Louis et al., 2003; Miller et al., 1982). Also, microcosm studies, using artificial seawater and tryptone as a carbon source, had previously shown that $V$. cholerae exhibits highest specific growth rates at moderate salinity (Singleton et al., 1982a). However, as far as we are aware, only two studies have been published where growth rates of $V$. cholerae $\mathrm{O} 1$ and of natural bacterial seawater flora were investigated and compared in sterilefiltered natural seawater. Reported specific growth rates (determined by microscopic cell counting) ranged from 0.013 to $0.596 \mathrm{~h}^{-1}$ for $V$. cholerae and from 0.004 to $0.404 \mathrm{~h}^{-1}$ for seawater microbial flora, respectively, at temperatures between 15 and $28{ }^{\circ} \mathrm{C}$ (Mourino-Perez et al., 2003; Worden et al., 2006). Whereas the specific growth rates of $V$. cholerae compare well with our freshwater results, the rates achieved by the lake water bacterial community were considerably higher in our experiments.

It should also be pointed out that the freshwater samples used were first autoclaved [to kill/inactivate autochthonous microbes able to pass $0.22 \mu \mathrm{m}$ membrane filters (Hahn, 2004)] and then $0.22 \mu \mathrm{m}$-filtered in order to remove crystalline particles interfering with the flow cytometric analysis. Although several chemical parameters did indicate little change before $(\mathrm{pH}=8.09 \pm 0.04 ; \mathrm{DOC}=100 \%)$ and after the treatment $(\mathrm{pH}=8.02 \pm 0.41 ; \mathrm{DOC}=104.7 \pm 18.3 \%)$ the concentration of $\mathrm{AOC}_{\mathrm{app}}$ increased consistently and was on average $141.5 \pm 18.3 \%$ after autoclaving. This can be explained by cell breakage and hydrolysis of organic matter during the treatment. Hence, this treatment certainly increased the concentration of $\mathrm{AOC}_{\mathrm{app}}$ and probably also affected the composition of the organic matter in the different freshwaters.

Several different approaches for the determination of AOC exist (Greenberg et al., 1993; Hammes \& Egli, 2005; Lechevallier et al., 1993), and thus care should be taken with comparison of absolute values from different studies. We therefore used the term 'apparent AOC' for results obtained with the method developed by Hammes \& Egli (2005). In general, the absolute values obtained with this method are about two to five times higher than those reported with the conventional method (Greenberg et al., 1993). Interestingly, whereas $V$. cholerae was able to grow at $\mathrm{AOC}_{\text {app }}$ concentrations as low as $100 \mu \mathrm{g} \mathrm{l^{-1 }}$, S. typhimurium did not show detectable growth in any of the freshwaters tested $\left(\mathrm{AOC}_{\text {app }}\right.$ concentrations up to $800 \mu \mathrm{g} \mathrm{l}{ }^{-1}$; Fig. 3b). This confirms recent reports where growth of $V$. cholerae was observed at low environmental carbon concentrations (Mourino-Perez et al., 2003; Worden et al., 2006), whereas Salmonella sp. was reported to grow only under highly eutrophic conditions as found, for example, in greywater (Ottoson \& Stenstrom, 2003) or in compost (Sidhu et al., 2001). Hence, S. typhimurium can be considered a strict copiotrophic enterobacterium unable to grow under environmental oligotrophic conditions (Winfield \& Groisman, 2003). This is obviously in contrast to the environmental survival and growth ability of $V$. cholerae.

The present results suggest a 'threshold' $\mathrm{AOC}_{\mathrm{app}}$ concentration for growth of $V$. cholerae in the range of 50$100 \mu \mathrm{g} \mathrm{l}^{-1}$. Interesting in this respect is the report of LeChevallier et al. (1996) who observed a significant negative correlation between the occurrence of coliforms in drinking-water systems and AOC concentrations lower than $100 \mu \mathrm{g}^{-1}$ (AOC concentration determined according to LeChevallier et al., 1993). Similarly, it was found that Aeromonas hydrophila only grew in tap water when starch was added at concentrations higher than $100 \mu \mathrm{g} \mathrm{Cl}^{-1}$ (Van der Kooij et al., 1980). Both authors explained the phenomenon by the existence of a substrate threshold concentration for growth in about the same range as observed for $V$. cholerae growing on natural AOC.

For a particular water source the observed cell increase at the expense of AOC for $V$. cholerae was always less than for the bacterial AOC-test community. This was the case for all waters tested, although the relative numerical cell yields of $V$. cholerae varied strongly between different water samples 
(0.12-0.62). There is certainly not a single reason for this variation. A first explanation is the fact that the spectrum of carbonaceous substrates utilizable for $V$. cholerae is narrower in comparison to that of the bacterial AOC-test community. Therefore, the numerical cell yield must be expected to be strongly dependent on quality of the AOC, i.e. the spectrum of compounds it consists of. A second explanation for varying numerical cell yields of $V$. cholerae could be that the average cell size of $V$. cholerae is changing under different conditions and is different from that of the community used for AOC assessment. Therefore, in spite of a positive correlation between $\mathrm{AOC}_{\mathrm{app}}$ concentration in different types of freshwater and numerical growth of $V$. cholerae (Fig. 3b), it will be very difficult to predict exactly the growth potential of $V$. cholerae in a water sample from the concentration of $\mathrm{AOC}_{\text {app }}$ only. From an ecological perspective, it would be interesting to investigate the relationship between algal growth, $\mathrm{AOC}_{\mathrm{app}}$ concentration and growth of $V$. cholerae. It is known that algae release considerable amounts of organic carbon compounds during photosynthesis (Münster, 1993) and that the occurrence of $V$. cholerae during algal blooms is elevated in estuary water systems (Epstein, 1993).

In addition to the concentration of utilizable carbon/ energy sources, temperature is a further key parameter that governs growth of heterotrophic microbes in aquatic systems (Moriarty \& Bell, 1993). Consequently, it has been proposed that an increase in temperature by a few degrees as a result of global warming might lead to a selective advantage for pathogens (see, e.g. Colwell, 1996). It was argued that a shift of the average environmental temperature towards the range optimal for growth for pathogens, which is typically around $37{ }^{\circ} \mathrm{C}$, would enable pathogenic bacteria to compete better for nutrients with the low temperature-adapted indigenous heterotrophic microbial flora. Supporting this hypothesis is that temperature is frequently reported to influence growth and occurrence of $V$. cholerae $\mathrm{O} 1$ in natural waters with low salinity (Huq et al., 2005; Louis et al., 2003). Also, the faecal indicator bacterium E. coli was reported to grow outside its host in tropical waters, but not at higher latitudes in the northern hemisphere, where the average annual water temperature is lower (Winfield \& Groisman, 2003). Our results clearly demonstrate a positive correlation between increasing temperature and the specific growth rate achieved by $V$. cholerae in freshwater within the range of $20-30{ }^{\circ} \mathrm{C}$ (Table 1 ). However, it appears from our data that in freshwater the ability of $V$. cholerae to compete with the lake water bacterial community for nutrients was not significantly affected. This result correlates with the observation of Louis et al. (2003), who found, in contrast to an estuarine environment, no year-to-year variability in the occurrence of $V$. cholerae $\mathrm{O} 1$ in a freshwater system. Certainly, it is difficult to extrapolate from our batch microcosm studies (where elevated temperatures did not favour $V$. cholerae when competing with the lake water bacterial community for substrates in freshwater), to the much more complex environmental situation where many other biotic and abiotic factors influence competitive microbial interactions. For example, temperature might influence competition in an indirect way by promoting algal growth and excretion of utilizable metabolites, grazing or viral lysis of pathogens and heterotrophic competitors. Competition experiments in the laboratory in AOC-limited continuous culture at different temperatures could provide more insight into the dynamics controlling growth and competition of $V$. cholerae with natural bacterial flora. In such a system competition could be followed over more extended periods of time and nutrient fluxes could be manipulated, simulating the varying nutrient supply in nature (Münster, 1993). The results presented here clearly demonstrate that growth of $V$. cholerae under oligotrophic conditions is not restricted to estuary or coastal waters but that this pathogen is able to grow in freshwater. Thus, as suggested earlier (Shapiro et al., 1999), freshwater aquifers - particularly when mesotrophic - might provide an environmental reservoir for $V$. cholerae, resulting in sporadic epidemic outbreaks originating from these waters. Our results also support the recent observation (Worden et al., 2006) that being attached to particles or higher organisms is not compulsory for the survival of this pathogen but that it is able to grow in a free-living state. The techniques described here open a way to well-controlled investigations for enhancing our understanding of the behaviour of $V$. cholerae in the freshwater environment and to improve risk assessment for the disease of cholera.

\section{ACKNOWLEDGEMENTS}

SPIEZ LABORATORY and the EU project TECHNEAU (018320) are acknowledged for financial support.

\section{REFERENCES}

Binsztein, N., Costagliola, M. C., Pichel, M., Jurquiza, V., Ramirez, F. C., Akselman, R., Vacchino, M., Huq, A. \& Colwell, R. (2004). Viable but nonculturable Vibrio cholerae $\mathrm{O} 1$ in the aquatic environment of Argentina. Appl Environ Microbiol 70, 7481-7486.

Borroto, R. J. (1997). Ecology of Vibrio cholerae serogroup 01 in aquatic environments. Rev Panam Salud Publica 1, 3-8.

Bourke, A. T., Cossins, Y. N., Gray, B. R., Lunney, T. J., Rostron, N. A., Holmes, R. V., Griggs, E. R., Larsen, D. J. \& Kelk, V. R. (1986). Investigation of cholera acquired from the riverine environment in Queensland. Med J Aust 144, 229-234.

Colwell, R. R. (1996). Global climate and infectious disease: the cholera paradigm. Science 274, 2025-2031.

Ducklow, H. W. \& Carlson, C. A. (1992). Oceanic bacterial production. Adv Microb Ecol 12, 113-181.

Egli, T. (1995). The ecological and physiological significance of the growth of heterotrophic microorganisms with mixtures of substrates. Adv Microb Ecol 14, 305-386.

Epstein, P. R. (1993). Algal blooms in the spread and persistence of cholera. Biosystems 31, 209-221.

Greenberg, A. E., Clesceri, L. S. \& Eaton, A. D. (1993). Standard Methods for the Examination of Water and Wastewater, 18th edn. Washington, DC: American Public Health Association. 
Hagström, Å., Larsson, U., Hörstedt, P. \& Normark, S. (1979). Frequency of dividing cells, a new approach to the determination of bacterial growth rates in aquatic environments. Appl Environ Microbiol 37, 805-812.

Hagström, Å., Ammerman, J. W., Henrichs, S. \& Azam, F. (1984). Bacterioplankton growth in seawater: II. Organic matter utilization during steady-state growth in seawater cultures. Mar Ecol Prog Ser 18, 41-48.

Hahn, M. W. (2004). Broad diversity of viable bacteria in 'sterile' $(0.2 \mu \mathrm{m})$ filtered water. Res Microbiol 155, 688-691.

Hammes, F. A. \& Egli, T. (2005). New method for assimilable organic carbon determination using flow-cytometric enumeration and a natural microbial consortium as inoculum. Environ Sci Technol 39, 3289-3294.

Hammes, F., Salhi, E., Köster, O., Kaiser, H. P., Egli, T. \& von Gunten, U. (2006). Mechanistic and kinetic evaluation of organic disinfection by-product and assimilable organic carbon (AOC) formation during the ozonation of drinking water. Water Res 40, 2275-2286.

Huq, A., Sack, R. B., Nizam, A. \& other authors (2005). Critical factors influencing the occurrence of Vibrio cholerae in the environment of Bangladesh. Appl Environ Microbiol 71, 4645-4654.

Ihssen, J. \& Egli, T. (2004). Specific growth rate and not cell density controls the general stress response in Escherichia coli. Microbiology 150, 1637-1648.

Jesudason, M. V., Balaji, V., Mukundan, U. \& Thomson, C. J. (2000). Ecological study of Vibrio cholerae in Vellore. Epidemiol Infect 124, 201-206.

LeChevallier, M. W., Schulz, W. \& Lee, R. G. (1991). Bacterial nutrients in drinking water. Appl Environ Microbiol 57, 857-862.

LeChevallier, M. W., Shaw, N. E., Kaplan, L. A. \& Bott, T. L. (1993). Development of a rapid assimilable organic carbon method for water. Appl Environ Microbiol 59, 1526-1531.

LeChevallier, M. W., Welch, N. J. \& Smith, D. B. (1996). Full-scale studies of factors related to coliform regrowth in drinking water. Appl Environ Microbiol 62, 2201-2211.

Lipp, E. K., Huq, A. \& Colwell, R. R. (2002). Effects of global climate on infectious disease: the cholera model. Clin Microbiol Rev 15, 757-770.

Louis, V. R., Russek-Cohen, E., Choopun, N. \& other authors (2003). Predictability of Vibrio cholerae in Chesapeake Bay. Appl Environ Microbiol 69, 2773-2785.

Miller, C. J., Drasar, B. S. \& Feachem, R. G. (1982). Cholera and estuarine salinity in Calcutta and London. Lancet 1, 1216-1218.

Moriarty, D. J. W. (1986). Measurement of bacterial growth rates in aquatic systems from rates of nucleic acid synthesis. Adv Microb Ecol 9 , 245-292.

Moriarty, D. J. W. \& Bell, R. T. (1993). Bacterial growth and starvation in aquatic environments. In Starvation in Bacteria, pp. 25-53. Edited by S. Kjelleberg. New York: Plenum Press.

Morita, R. Y. (1997). Bacteria in Oligotrophic Environments. New York: Chapman \& Hall.

Mourino-Perez, R. R., Worden, A. Z. \& Azam, F. (2003). Growth of Vibrio cholerae $\mathrm{O} 1$ in red tide waters off California. Appl Environ Microbiol 69, 6923-6931.

Münster, U. (1993). Concentrations and fluxes of organic carbon substrates in the aquatic environment. Antonie Van Leeuwenhoek 63, $243-274$
Nogueira, J. M., Rodrigues, D. P. \& Hofer, E. (2002). Viability of Vibrio cholerae $\mathrm{O} 1$ in different types of water under experimental conditions. Cad Saude Publica 18, 1339-1345.

Ottoson, J. \& Stenstrom, T. A. (2003). Faecal contamination of greywater and associated microbial risks. Water Res 37, 645-655.

Reichert, P. (1998). AQUASIM 2.0 - Tutorial, Computer Program for the Identification and Simulation of Aquatic Systems. Dübendorf, Switzerland: EAWAG.

Reidl, J. \& Klose, K. E. (2002). Vibrio cholerae and cholera: out of the water and into the host. FEMS Microbiol Rev 26, 125-139.

Robarts, R. D. \& Zohary, T. (1993). Fact or fiction - bacterial growth rates and production as determined by [methyl-3H]-thymidine? Adv Microb Ecol 13, 371-425.

Rodo, X., Pascual, M., Fuchs, G. \& Faruque, A. S. (2002). ENSO and cholera: a nonstationary link related to climate change? Proc Natl Acad Sci U S A 99, 12901-12906.

Shapiro, R. L., Otieno, M. R., Adcock, P. M., Phillips-Howard, P. A., Hawley, W. A., Kumar, L., Waiyaki, P., Nahlen, B. L. \& Slutsker, L. (1999). Transmission of epidemic Vibrio cholerae O1 in rural western Kenya associated with drinking water from Lake Victoria: an environmental reservoir for cholera? Am J Trop Med Hyg 60, 271-276.

Sidhu, J., Gibbs, R. A., Ho, G. E. \& Unkovich, I. (2001). The role of indigenous microorganisms in suppression of Salmonella regrowth in composted biosolids. Water Res 35, 913-920.

Simon, M., Grossart, H.-P., Schweitzer, B. \& Ploug, H. (2002). Microbial ecology of organic aggregates in aquatic ecosystems. Aquat Microb Ecol 28, 175-211.

Singleton, F. L., Attwell, R., Jangi, S. \& Colwell, R. R. (1982a). Effects of temperature and salinity on Vibrio cholerae growth. Appl Environ Microbiol 44, 1047-1058.

Singleton, F. L., Attwell, R. W., Jangi, S. \& Colwell, R. R. (1982b). Influence of salinity and organic nutrient concentration on survival and growth of Vibrio cholerae in aquatic microcosms. Appl Environ Microbiol 43, 1080-1085.

Van der Kooij, D. (1992). Assimilable organic carbon as indicator of bacterial regrowth. J Am Water Works Assoc 84, 57-65.

Van der Kooij, D. (2002). Assimilable organic carbon (AOC) in treated water: determination and significance. In Encyclopedia of Environmental Microbiology, pp. 312-327. Edited by G. Bitton. Hoboken, NJ: John Wiley \& Sons.

Van der Kooij, D., Visser, A. \& Hijnen, W. A. M. (1980). Growth of Aeromonas hydrophila at low concentrations of substrates added to water. Appl Environ Microbiol 39, 1198-1204.

West, P. A. \& Lee, J. V. (1982). Ecology of Vibrio species, including Vibrio cholerae, in natural waters in Kent, England. J Appl Bacteriol 52, 435-448.

Winfield, M. D. \& Groisman, E. A. (2003). Role of nonhost environments in the lifestyles of Salmonella and Escherichia coli. Appl Environ Microbiol 69, 3687-3694.

Worden, A. Z., Seidel, M., Smriga, S., Wick, A., Malfatti, F., Bartlett, D. \& Azam, F. (2006). Trophic regulation of Vibrio cholerae in coastal marine waters. Environ Microbiol 8, 21-29.

Yamai, S., Okitsu, T. \& Katsube, Y. (1996). Isolation and incidence of Vibrio cholerae from river water. Kansenshogaku Zasshi 70, 1234-1241.

Edited by: A. Holmes 